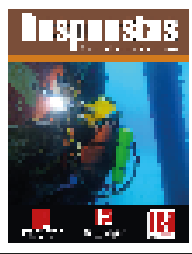

Original Article
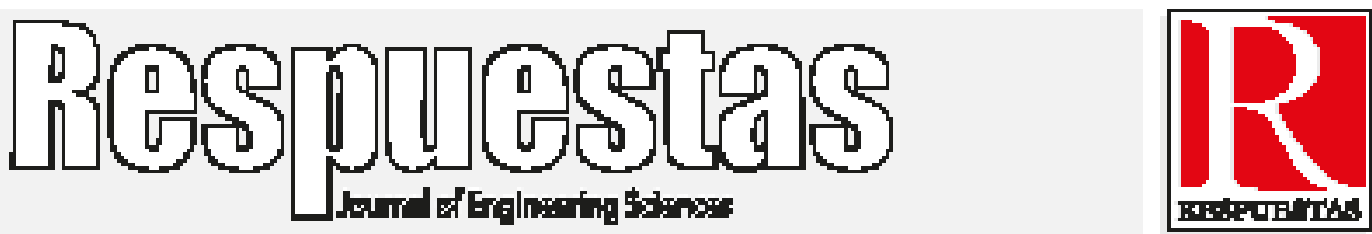

\title{
Cement substitutes: a bibliometric analysis of trends and contributions from 2013 to 2018
}

Sustitutos del cemento: un análisis bibliométrico de las tendencias y aportes desde 2013 hasta 2018

Yessica Carolina Villamizar-Delgado ${ }^{1}$, Leonardo Cely-Illera ${ }^{2 *}$, Jairo Cely-Niño ${ }^{3}$

'Ingeniera industrial, yessicacarolinavd@ufps.edu.co, Orcid: 0000-0003-0353-4553, Universidad Francisco de Paula Santander, Cúcuta, Colombia.

2"Magister en Ciencia y Tecnología de Materiales, leonardocely@ufps.edu.co, Orcid: 0000-0002-9476-7100, Universidad Francisco de Paula Santander, Cúcuta, Colombia.

3Ingeniero Mecánico, jairowilgbertocn@ufps.edu.co,Orcid: 0000-0001-6469-0280,Universidad Francisco de Paula Santander, Cúcuta, Colombia.

How to cite: Y.C. Villamizar-Delgado, L. Cely-Illera, J. Cely-Niño, "Cement substitutes: a bibliometric analysis of trends and contributions from 2013 to 2018 ". Respuestas, vol. 25 , no. 1, pp. 195-201, 2020.

Received on June 30, 2019; Approved on November 10, 2019

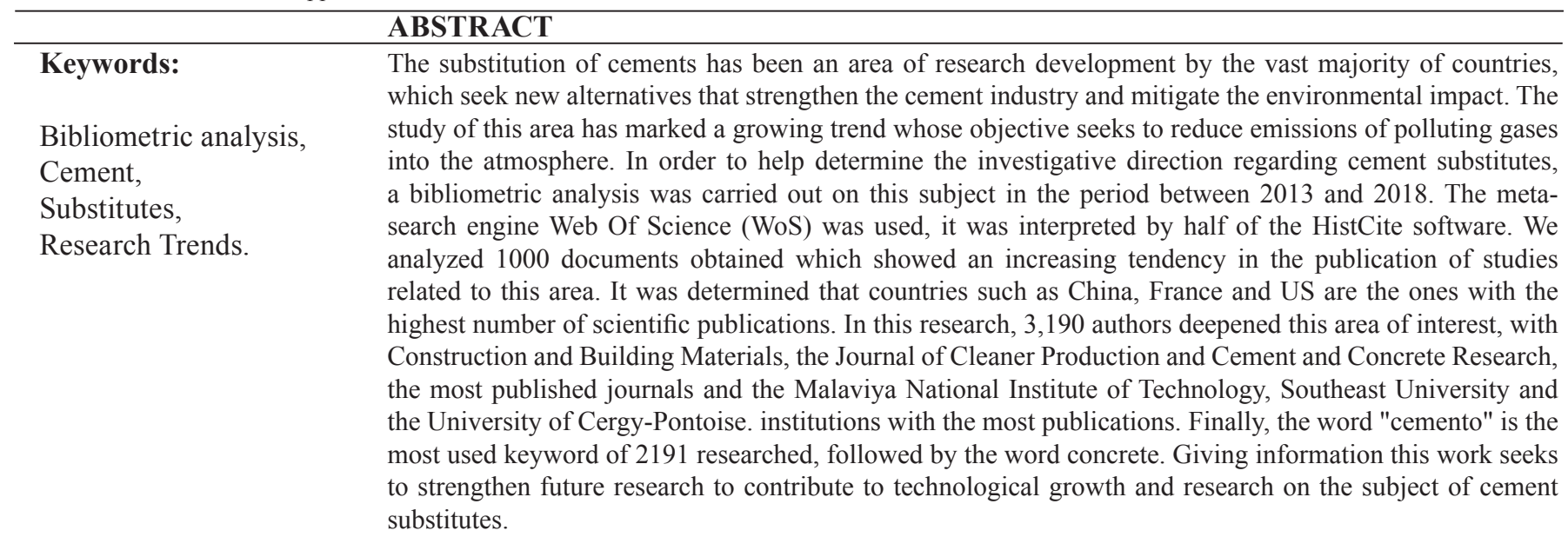

\begin{tabular}{ll}
\hline RESUMEN \\
\hline Palabras clave: & $\begin{array}{l}\text { La sustitución de cementos ha sido un área de desarrollo investigativo por la gran mayoría de países, los } \\
\text { cuales buscan nuevas alternativas que fortalezcan la industria cementera y mitiguen el impacto ambiental. El }\end{array}$ \\
Análisis bibliométrico, & $\begin{array}{l}\text { estudio de esta área ha marcado una tendencia creciente cuyo objetivo busca la disminución en las emisiones } \\
\text { de gases contaminantes a la atmosfera. En busca de ayudar a determinar el rumbo investigativo referente }\end{array}$ \\
Cemento, & a sustitutos del cemento se realizó un análisis bibliométrico sobre este tema en el periodo comprendido \\
Tendencias de & entre el año 2013 hasta el año 2018. Se empleó el metabuscador Web Of Science (WoS), se interpretó por \\
Investigación. & medio del software HistCite. Se analizaron 1000 documentos obtenidos los cuales mostraron una tendencia \\
& creciente en la publicación de estudios relacionados con esta área. Se determinó que países como China, \\
& Francia y Estados Unidos son los de mayor número de publicaciones científicas. En esta investigación 3.190 \\
& autores profundizaron esta área de interés, siendo Construction and Building Materials, Journal of Cleaner \\
& Production y Cement and Concrete Research, las revistas con más documentos publicados y Malaviya \\
& National Institute of Technology, Southeast University y Université de Cergy-Pontoise, las instituciones con \\
& mayores publicaciones. Finalmente, la palabra cement es la palabra clave más utilizada de 2191 investigadas, \\
seguida por la palabra concrete. Dando a conocer esta información se busca fortalecer futuras investigaciones & para aportar en el crecimiento tecnológico e investigativo en el tema de sustitutos del cemento.
\end{tabular}

*Corresponding author.

E-mail Address:leonardocely@ufps.edu.co (Leonardo Cely-Illera)

(c) $($ ) $९$ Peer review is the responsibility of the Universidad Francisco de Paula Santander. 


\section{Introduction}

In recent years, the use of mineral additives in concrete has become common practice in the construction and civil engineering industry [1]. Cement is an agglomerating material that has the property of setting and hardening in the presence of water. The production of concrete, the second most used material worldwide after water, is approximately 11.5 billion tons each year [2]. The cement industry plays a crucial role in reducing $\mathrm{CO} 2$ emissions because it represents a substantial proportion of global emissions [3]. It was found that for the manufacturing process of one ton of ordinary cement, about one ton of $\mathrm{CO} 2$ is released into the atmosphere. Given this level of pollution to the environment, it is necessary to include mineral additions to the concrete mix to mitigate the emission of polluting gases that harm the quality of life of people [1], [4].

The importance of implementing some alternative substitutes such as fly ash, unpolluted marine sediments, alternative geopolymers, marble dust, rubber tire waste, rice husk ash, waste glass, wool waste, agricultural waste, and thick coconut shells in cement, are the basis for creating environmentally friendly products that provide low pollution in the process of obtaining concrete and additionally improve its properties [5], [6].

Since cement is an important element in construction, it is necessary to be aware of the research trends on this subject, so that future research will have an analytical and sustainable focus. Currently, there are a large number of publications in this area, which creates problems in the analysis of information. For this reason, recently the tool called bibliometric analysis is being used to study and analyze scientific literature, through the application of mathematical and statistical methods that provide a quantitative analysis of the texts. With this method, it is possible to measure the research contribution of authors, institutions, countries and the impact of the journals. It also emphasizes the strengths and weaknesses of the research. The data for the bibliometric analysis were filtered from information obtained from the Web of Science (WoS) database in the time period from January 2013 to mid-October 2018, when the writing of this article began. The results generated are quantitative and qualitative related, and were tabulated through the HistCite program. Through this means, the information on research trends in the construction field is gathered and analyzed, specifically in cement substitutes and additives, by making a global outline where a large number of trends can be observed that may be of interest for future research.

This work presents a scientometric analysis of the information available until mid October 2018, with the objective of examining through scientific documents, the information necessary to measure in a quantitative and qualitative way the world-wide tendencies of investigation as far as cement substitutes are concerned. The main contribution of this article is the measurement of the impact on the participation of recognized authors, scientific institutions, journals and most influential countries around the world, in relation to the research topic.

\section{Materials and methods}

In order to identify the main actors surrounding this research topic, 1000 documents related to the topic of cement substitutes were collected and a bibliometric study was carried out. These documents were obtained through information from the specialized Web of Science (WoS) database, which is a meta-search engine that allows journals to be evaluated and compared using the citation data found. Web of Science (WoS), is the only source of journal citation data and includes virtually all areas of science, technology, and social science. Reports show the most frequently cited journals with the greatest impact.

This information was then analyzed, using the HistCite statistical tool, which is a computer tool that facilitates bibliometric analysis and visualization of the information [7]. The selection of the documents was carried out in a period between 2013 and mid-October 2018. All the documents found in the database were evaluated considering the most relevant thematic categories such as authors, institutions, countries, keywords, journals and types of documents. All the information obtained was represented by means of tables and graphs, which allow the personalization of the studied results according to the user's criteria. 


\section{Results and Discussion}

\section{Publication types and language}

Six types of documents were observed, with the article type being the most frequent with a total of 825 publications $(82.5 \%)$, followed by documents such as minutes with 126 publications (12.6\%), review articles with 25 publications $(2.5 \%)$, procedural articles with 15 publications $(1.5 \%)$, book chapters with 8 publications $(0.08 \%)$, and editorial material with 1 publication $(0.1 \%)$. When analyzing the information it was observed that the English language is the most used to write most of the publications in this area with $97.1 \%$ of the total of documents, this result is possibly due to the fact that it is the international language most used by the researchers at world-wide level. [8], [9]. In table I, the languages used in the writing of the publications studied are represented.

Tabla I. Idiomas de redacción de las publicaciones estudiadas (DP: Cantidad de Publicaciones, TLCS: Total de Citaciones Locales, TGCS: Total de Citaciones Globales)

\begin{tabular}{|c|c|c|c|}
\hline LANGUAGE & DP & TLCS & TGCS \\
\hline English & 971 & 482 & 6546 \\
\hline French & 7 & 0 & 2 \\
\hline Portuguese & 7 & 0 & 3 \\
\hline German & 4 & 0 & 0 \\
\hline Russian & 3 & 0 & 0 \\
\hline Korean & 2 & 0 & 0 \\
\hline English & 2 & 0 & 1 \\
\hline Turkish & 2 & 0 & 0 \\
\hline Chinese & 1 & 0 & 3 \\
\hline Hungarian & 1 & 0 & 0 \\
\hline
\end{tabular}

\section{Publications by year}

Figure 1 below shows the production of publications per year, from January 2013 to October 2018.

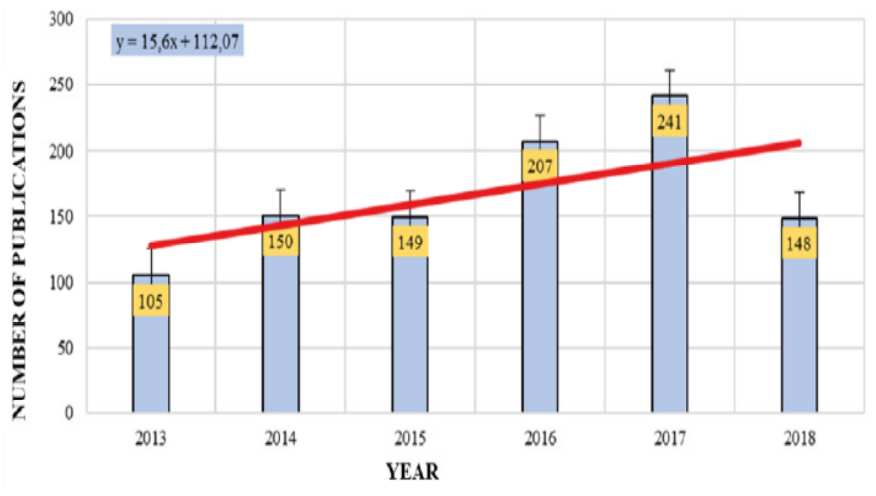

Figure 1. Number of publications from January 2013 to October 2018

It is detailed that an increasing trend in publications has been maintained throughout the years, with the exception of 2018 when a reduction in the production of scientific texts can be seen. However, this could be due to the time of writing of this article, which was made at the end of October 2018, which would mean, according to the trend shown in the figure, an increase in publications with reference to previous years. By generating a trend line in the data provided, a slope of 15.6 publications per year was obtained. This shows that the search for cement substitutes is an important issue for the scientific community since it not only helps scientific knowledge, which is the main objective of this type of publication, but also, with this type of research, helps to reduce pollution in the environment [10] - [12].

\section{Participation of authors with more publications}

The main basis of the publications are the authors, who give meaning and orientation to each text, that is why for this bibliometric analysis it is important to know which authors have contributed to the development of this topic. The distribution analysis shows the authors who have reported or disseminated their advances and research in any of the scientific media. In this research 3,190 authors deepened this area of interest. However, only the 10 authors with the highest number of publications will be shown.

The research shows the impact that the publications of these authors have, these are measured by the TLCS indicator, (Total Local Citation Score), indicator that is used to measure the research influence of the authors and their publications. The list is headed by De Brito $\mathrm{J}$, followed by Gelinsky M, Schumacher M, these three being the most relevant authors with 8 publications each. 
It should be noted that, when analyzing figure 2, it can be stated that Gelinsky $M$ and Schumacher $M$ are the authors with the highest quality in their publications due to their higher TLCS values, as shown by the trend line, which allows us to determine that they are part of the group of authors most cited worldwide [13].

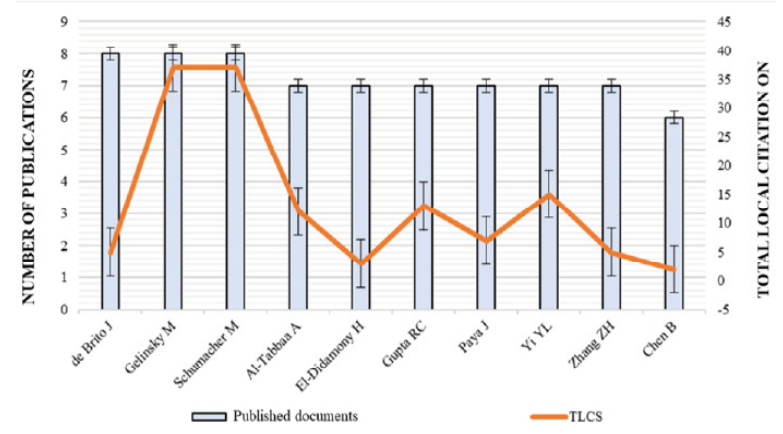

Figure 2. Authors with the largest number of publications and FTAs from January 2013 to October 2018

\section{Distribution by magazines}

Table II, shows the ten main scientific journals that address the central theme of study, the journal with the highest production is Construction and Building Materials with 177 publications, corresponding to $17.7 \%$ of the total number of publications of the journals.

Construction and Building Materials, is an international journal dedicated to research and innovative use of materials in construction, likewise has the highest number of citations (TLCS $=143$ ). In second place, this Journal of Cleaner Production with 53 publications (5.3\%), in addition, there is Cement and Concrete Research with 22 publications (2.2\%) and Cement \& Concrete Composites with 18 publications $(1.8 \%)$.

Although the journals included in this study have an industrial focus, it is very significant to see that the cement industry is making efforts to mitigate the pollution levels it produces, looking for new alternatives that generate a great benefit to the industry and the environment. Through the FTAs and TGCS it is determined that the journals could be considered high level due to the quality of their articles [4], [14] and [15].
Table II. The 10 journals with the highest number of publications

\begin{tabular}{|c|c|c|c|c|}
\hline JOURNALS & DP & DP $\%$ & TLCS & TGCS \\
\hline Constrnction and Building Materials & 177 & $17.7 \%$ & 143 & 1677 \\
\hline Journal of Cleaner Production & 33 & $5.3 \%$ & 45 & 630 \\
\hline Cement and Concrete Research & 22 & $2.2 \%$ & 15 & 377 \\
\hline Cement \& Concrete Composites & 18 & $1.8 \%$ & 8 & 194 \\
\hline Materials and Structures & 17 & $1.7 \%$ & 9 & 141 \\
\hline Journal of Materials in Civil Fngineering & 15 & $1.5 \%$ & 8 & 63 \\
\hline Journal of Thermal Analysis and Calorimetry & 14 & $1.4 \%$ & 3 & 44 \\
\hline Acta Biomaterialia & 12 & $1.2 \%$ & 70 & 413 \\
\hline Materials Science \& Engineering c-Materials for Biological Applications & 12 & $1.2 \%$ & 14 & 145 \\
\hline Advances in Cement Research & 10 & $1.0 \%$ & 8 & 56 \\
\hline
\end{tabular}

\section{Countries with the largest number of publications}

The analysis of the distribution by country with the greatest number of publications shows those that have reported or disseminated their advances and research in any of the scientific media. In this case, the search for cement substitutes is an area of interest at the global level [16], [17] and [18]. In this case, the search for cement substitutes is an area of interest worldwide [16], [17] and [18]. In Table III, the 10 countries with the highest number of publications will be presented. First, we have the Republic of China with a total of 144 publications, followed by France with 83 publications, the United States with 78 published documents, Spain with 73 documents, India with 71 published documents and Brazil with 56 publications.

Table III. Countries with the highest number of publications.Fuente. Autores

\begin{tabular}{|c|c|c|c|c|c|}
\hline COLNTRY & DP & DP\% & TLCS & TLCS\% & TGCS \\
\hline China & 144 & $14.4 \%$ & 69 & $14.3 \%$ & 957 \\
\hline France & 83 & $8.3 \%$ & 77 & $16 \%$ & 710 \\
\hline USA & 78 & $7.8 \%$ & 33 & $6.8 \%$ & 382 \\
\hline Spain & 73 & $7.3 \%$ & 54 & $11.2 \%$ & 580 \\
\hline India & 71 & $7.1 \%$ & 37 & $7.7 \%$ & 48.5 \\
\hline Brazil & 56 & $5.6 \%$ & 11 & $2.3 \%$ & 143 \\
\hline Ukraine & 53 & $5.3 \%$ & 41 & $8.5 \%$ & 681 \\
\hline Algeria & 49 & $4.9 \%$ & 21 & $4.4 \%$ & 140 \\
\hline South Korea & 44 & $4.4 \%$ & 22 & $4.6 \%$ & 260 \\
\hline Germany & 42 & $4.2 \%$ & 54 & $11.2 \%$ & 545 \\
\hline
\end{tabular}

Table III shows the impact of citations measured by the FTA indicator. It can be seen that China generates the greatest number of publications worldwide, but the articles dedicated to this topic generated by France are the most referenced, that is, they are the ones with the greatest impact and at the same time have the highest FTA index. However, it is important to note that publications from the Republic of China tend to have more references at a global level (TGCS), which can be seen in table III. Additionally, it can be said that, among the 10 countries with the highest values of FTAs, there are 5 developed countries (United States, Spain, Germany, France and China) and 5 developing countries (India, Brazil, 
Ukraine, Algeria and South Korea).

\section{More productive institutions}

The contributions of articles published by institutes related to cement substitutes show the research capacity and activities of institutions around the world in reference to this topic. Table IV (top 10 institutions) shows in the first places Malaviya National Institute of Technology and Southeast University both with 14 publications, followed by Université de Cergy-Pontoise with 13 publications. Using TLCS, the three most important institutions in terms of citations were Technische Universität Dresden (37), Malaviya National Institute of Technology (21) and Southeast University (20), which already surpasses the next institution Université de Cergy-Pontoise with almost four times (6) as shown in Table IV.

In the top 10 of the most productive institutes, unfortunately no institute was found in South America, showing the poor research carried out in this part of the continent. It should be noted that the institutes from Germany and in second place those from India are the ones with the highest global references (TGCS), evidencing that India is definitely the developing country that is intensifying the production of research in cement substitutes as a means to achieve the social and economic development of the country [19], [20].

Table IV. The 10 most productive institutions.

\begin{tabular}{|c|c|c|c|c|}
\hline N. & INSTITUTIONS & DP & TLCS & TGCS \\
\hline 1 & Malaviya National Institute of Technology & 14 & 21 & 197 \\
\hline 2 & Southeast University & 14 & 20 & 135 \\
\hline 3 & Universit́s de Cergy-Pontoise & 13 & 6 & 30 \\
\hline 4 & Wuhar University of Technology & 11 & 3 & 26 \\
\hline 5 & Consejo Superior de Investigaciones Cientificas - CSIC - & 10 & 3 & 36 \\
\hline 6 & University in Czech Republic & 10 & 0 & 29 \\
\hline 7 & Zagazig Universiy & 10 & 3 & 47 \\
\hline 8 & Technische Universitat Dresden & 9 & 37 & 198 \\
\hline 9 & Universidade de Aveiro & 9 & 4 & 64 \\
\hline 10 & Université de La Rochelle & 9 & 3 & 66 \\
\hline
\end{tabular}

\section{Keywords}

An author's keywords in an article may provide details about the topic of the article, this may provide trends in searches for information in a particular field [21], [22]. In compiling the information under study from 2013 to 2018 , a total of 2,191 keywords were displayed, which are mentioned in articles concerning cement substitutes. Of these, the 10 most important keywords in the entire information collection were highlighted, with the word cement being the most associated with all the results obtained, and obtaining a number of citations in the scientific articles of 343 , followed by the word concrete (248), properties (188), ash (138), effect (105), mechanical (100), substitution (82), waste (81), slag (80) and strength (78). Results based on the authors' keywords were used to analyze research behavior on the subject of cement substitutes. In the present study, article titles, author keywords and abstracts were combined for analysis [23].

\section{Conclusions}

The bibliometric analysis carried out between January 2013 and October 2018, shows that there is a marked trend of increase in the research of substitutes for cement. Based on this study, we detail the impact on the participation of authors, institutions, journals and developed and developing countries more influential in relation to the subject of research. In addition, it is observed not only the search of new products with better characteristics but the importance of mitigating the unfavorable effects that are caused to the environment in the productive processes of this type of materials.

It is observed that the two authors with the highest productivity and quality in their publications are Gelinsky $\mathrm{M}$ and Schumacher M, however, the institutions to which they belong do not maintain a high level of productivity in comparison with institutions such as Technische Universität Dresden, Malaviya National Institute of Technology and Southeast University.

The TLCS and TGCS indicators determined that there is a great number of publications that speak about the research topic, but it does not evidence in a clear way the most relevant articles, only the most cited ones. This could be improved by classifying the documents in specific areas of science and by category of publication, in spite of that, it is detailed, that the magazine Construction and Building Materials with $17.7 \%$ and Journal of Cleaner Production with $5.3 \%$ are the magazines with the highest production at scientific level.

In the same sense, it is evident that the English language with $97.1 \%$ is the most used to write the majority of the publications, mainly those types article with $82.5 \%$, where it is detailed, besides that the word cement with 343 citations and the concrete with 248 are the ones of greater mention in the scientific community. 
Finally, it is regrettable that no institute, author and/or important publication has been found in this part of South America, leaving in evidence, the poor research carried out by researchers and institutions of our continent and the importance of continuing to carry out research like this to focus on the most important points within the scientific field.

\section{Acknowledgements}

The authors would like to thank the Eduardo Cote Lamus Library and the Francisco de Paula Santander University for the support received in the development of this research, and the lending of resources.

\section{Referencias}

[1] C. Nwaoha, M. Beaulieu, P. Tontiwachwuthikul and M. D. Gibson, "Techno-economic analysis of $\mathrm{CO} 2$ capture from a 1.2 million MTPA cement plant using AMP-PZ-MEA blend", International Journal of Greenhouse Gas Control, vol. 78, pp. 400-412, 2018. doi: 10.1016/j.ijggc.2018.07.015.

[2] J. Cárdenas Pulido, J. Lizarazo-Marriaga and W. Aperador Chaparro, "Comportamiento mecánico de sistemas cementantes ternarios (cemento portland - ceniza volante - escoria de alto horno)", Revista Latinoamericana de Metalurgia y Materiales, vol. 36, no. 2, pp. 201-216, 2016.

[3] B. Qu, A. Martin, J. Y. Pastor, A. Palomo and A. Fernández-Jiménez, "Characterisation of pre-industrial hybrid cement and effect of precuring temperature", Cement and Concrete Composites, vol. 73, pp. 281-288, 2016. doi: 10.1016/J.cemconcomp.2016.07.019.

[4] K.-H. Yang, K.-H. Lee, J.-K. Song and M.-H. Gongd, "Properties and sustainability of alkaliactivated slag foamed concrete", Journal of Cleaner Production, vol. 68, pp. 226-233, 2014. doi: 10.1016/j.jclepro.2013.12.068.

[5] K. Shwekat and H.-C. Wu, "Benefit-cost analysis model of using class $F$ fly ash-based green cement in masonry units", Journal of Cleaner Production, vol. 198, pp. 443-451, 2018. doi: 10.1016/j.jclepro.2018.06.229.

[6] Z. Zhao, M. Benzerzour, N.-E. Abriak, D. Damidot, L. Courard and D. Wang, "Use of uncontaminated marine sediments in mortar and concrete by partial substitution of cement", Cement and Concrete Composites, vol. 93, pp. 155-162, $2018 . \quad$ doi: $10.1016 / \mathrm{j}$. cemconcomp.2018.07.010.

[7] D. Lucio-Arias and L. Leydesdorff, "Mainpath analysis and path-dependent transitions in HistCite (TM)-based historiograms", Journal of the American Society for Information Science and Technology, vol. 59, no. 12, pp. 1948-1962, 2008.

[8] C. Carreño-Gallardo, A. Tejeda-Ochoa, O. I. Perez-Ordone, J. E. Ledezma-Sillas, D. Lardizabal-Gutierrez, C. Prieto-Gomez, J. A. Valenzuela-Grado, F. C. Robles Hernandez and J. M. Herrera-Ramireza, "In the CO2 emission remediation by means of alternative geopolymers as substitutes for cements", Journal of Environmental Chemical Engineering, vol. 6, no. 4, pp. 4878-4884, 2018. doi: 10.1016/j. jece.2018.07.033.

[9] D. Kumar Ashish, "Feasibility of waste marble powder in concrete as partial substitution of cement and sand amalgam for sustainable growth", Journal of Building Engineering, vol. 15, pp. 236-242, 2018. doi: 10.1016/j. jobe.2017.11.024.

[10] M. A. Fernández-Ruiz, L. M. Gil-Martín, J. F. Carbonell-Márquez and E. Hernández-Montes, "Epoxy resin and ground tyre rubber replacement for cement in concrete: Compressive behaviour and durability properties", Construction and Building Materials, vol. 173, pp. 49-57, 2018. doi: 10.1016/j.conbuildmat.2018.04.004. 
[11] M. M. Younes, H. Abdel-Rahman and M. Khattab, "Utilization of rice husk ash and waste glass in the production of ternary blended cement mortar composites", Journal of Building Engineering, vol. 20, pp. 42-50, 2018.

[12] A. Sarabia Guarín, J. Sánchez Molina and J. C. Leyva Diaz, "Uso de nutrientes tecnológicos como materia prima en la fabricación de materiales de construcción en el paradigma de la economía circular", Respuestas, vol. 22, no. 1, pp. 6-16, 2017. doi: $10.22463 / 0122820 X .815$.

[13] L. Waltman, "A review of the literature on citation impact indicators", Journal of Informetrics, vol. 10, no. 2, pp. 365-391, 2016. doi: 10.1016/j.joi.2016.02.007.

[14] I. Sun Kim, S. Yeong Choi and E. Ik Yanga, "Evaluation of durability of concrete substituted heavyweight waste glass as fine aggregate", Construction and Building Materials, vol. 184, pp. 269-277, 2018. doi: 10.1016/j. conbuildmat.2018.06.221.

[15] H. Beushausen, R. Torrent and M. G. Alexandera, "Performance-based approaches for concrete durability: State of the art and future research needs", Cement and Concrete Research, vol. 119, pp. 11-20, 2019. doi: 10.1016/j. cemconres.2019.01.003.

[16] T. A. Escorcia-Otálora and R. A. Poutou-Piñales, "Análisis bibliométrico de los artículos originales publicados en la revista Universitas Scientiarum (1987-2007)", Universitas Scientiarum, vol. 13, no. 3, pp. 236-244, 2008.

[17] A. Benavides Gamero, G. Valencia Ochoa and L. Meriño Stand, "Análisis de las tendencias de los resultados de investigación en producción de biodiésel de 2009 a 2016", Prospectiva, vol. 16, no. 2, pp. 89-93, 2018. doi: 10.15665/ rp.v16i2.1656.
[18] M. M. Younes, H. A. Abdel-Rahman and M. M. Khattab, "Utilization of rice husk ash and waste glass in the production of ternary blended cement mortar composites", Journal of Building Engineering, vol. 20, pp. 42-50, 2018. doi: 10.1016/j.jobe.2018.07.001.

[19] V. Flores-Alés, V. Jiménez-Bayarri and A. Pérez-Fargallob, "Influencia de la incorporación de vidrio triturado en las propiedades y el comportamiento a alta temperatura de morteros de cemento", Boletín de la Sociedad Española de Cerámica y Vidrio, vol. 57, no. 6, pp. 257-265, 2018. doi: 10.1016/j.bsecv.2018.03.001.

[20] N. Sathiparan and H. De Zoysa, "The effects of using agricultural waste as partial substitute for sand in cement blocks", Journal of Building Engineering, vol. 19, pp. 216-227, 2018. doi: 10.1016/j.jobe.2018.04.023.

[21] K. Cifuentes Thorrens, A. Rodríguez Peña and G. Valencia Ochoa, “Análisis bibliométrico de las investigaciones en sistemas híbridos de energía renovables Solar - Eólica comprendido entre el año 2000 a 2017", Revistas Espacios, vol. 39, no. 22, pp. 21-28, 2018. doi: dx.doi.org/10.1016/j. rser.2014.07.113.

[22] L. J. Montilla Peña, "Análisis bibliométrico sobre la producción científica archivística en la Red de Revistas Científicas de América Latina y el Caribe (Redalyc) durante el período 2001-2011", Biblios, vol. 48, pp. 1-11, 2012. doi: 10.5195/biblios.2012.65.

[23] I. Sarmiento Nieto, Y. Cárdenas Escorcia and G. Valencia Ochoa, "Análisis cienciométrico de la investigación de sistemas fotovoltaicos integrados a edificios desde el año 2000 a 2017”, Revista Espacios, vol. 38, no. 47, pp. 29-40, 2017. doi: 10.1016/j.apenergy.2009.06.011. 